OPEN ACCESS

Edited by:

M. Teresa De La Morena

Seattle Children's Hospital,

United States

Reviewed by:

Satya Yadav,

Medanta the Medicity Hospital, India

Jignesh D. Dalal,

Case Western Reserve University,

United States

Ramya Uppuluri,

Apollo Speciality Hospitals, India

Jan Stary,

University Hospital in Motol, Czechia

Herbert Pichler

St. Anna Kinderspital, Austria

Aleksandra Petrovic,

Johns Hopkins All Children's Hospital,

United States

*Correspondence:

Emmanuel Katsanis

ekatsani@arizona.edu

orcid.org/0000-0003-1466-6965

Specialty section:

This article was submitted to

Pediatric Immunology,

a section of the journa

Frontiers in Pediatrics

Received: 30 December 2020

Accepted: 23 September 2021

Published: 27 October 2021

Citation:

Smith J, Alfonso JH, Reddivalla N, Angulo $P$ and Katsanis E (2021) Case Report: Haploidentical Bone Marrow

Transplantation in Two Brothers With

Wiskott-Aldrich Syndrome Using Their

Father as the Donor.

Front. Pediatr. 9:647505.

doi: 10.3389/fped.2021.647505

\section{Case Report: Haploidentical Bone Marrow Transplantation in Two Brothers With Wiskott-Aldrich Syndrome Using Their Father as the Donor}

\author{
Jasmine Smith $^{1,2}$, Jessica Hass Alfonso ${ }^{1,2}$, Naresh Reddivalla ${ }^{1,3}$, Pablo Angulo $^{1,3}$ and \\ Emmanuel Katsanis ${ }^{1,2,4,5,6,7 *}$
}

${ }^{1}$ Department of Pediatrics, University of Arizona, Tucson, AZ, United States, ${ }^{2}$ Banner University Medical Center, Tucson, AZ, United States, ${ }^{3}$ Banner Children's at Desert, Mesa, AZ, United States, ${ }^{4}$ Department of Immunobiology, University of Arizona, Tucson, AZ, United States, ${ }^{5}$ Department of Medicine, University of Arizona, Tucson, AZ, United States, ${ }^{6}$ Department of Pathology, University of Arizona, Tucson, AZ, United States, ${ }^{7}$ The University of Arizona Cancer Center, Tucson, $A Z$, United States

Wiskott-Aldrich syndrome (WAS) is an X-linked genetic disorder with a variable phenotypic expression that includes thrombocytopenia, eczema, and immunodeficiency. Some patients may also exhibit autoimmune manifestations. Patients with WAS are at increased risk of developing malignancies such as lymphoma. Allogeneic hematopoietic cell transplantation remains the only curative treatment. Haploidentical bone marrow transplantation (haplo-BMT) with post-transplant cyclophosphamide (PT-CY) has more recently been applied in WAS. Here, we report two brothers who underwent successful T-cell replete haplo-BMT with PT-CY at ages 9 months and 4 years using their father as the donor. Our myeloablative regimen was well-tolerated with minimal organ toxicity and no acute or chronic graft vs. host disease (GvHD). Haplo-BMT may be considered as a safe and effective option for patients with WAS who do not have available human leukocyte antigen (HLA) matched donors.

Keywords: Wiskott Aldrich syndrome (WAS), haploidentical hematopoietic stem cell transplantation, cyclophosphamide, myeloablative allogeneic hematopoietic cell transplantation, immunodeficiency

\section{INTRODUCTION}

Wiskott-Aldrich syndrome (WAS) is an X-linked disorder characterized by the triad of microthrombocytopenia, eczema, and immunodeficiency, though all three are not required for diagnosis, as some patients may present with partial or variable phenotypic expression (1-3). Patients with WAS are also at increased risk for autoimmune manifestations as well as malignancies, especially lymphomas. WAS is caused by mutations in the WAS gene, which encodes the WAS protein involved in actin polymerization, cytoskeleton remodeling, signaling events, and the immunologic synapse (4-7). With the inappropriate functioning of the WAS gene, both T and $B$ cells are affected, leading to severe immunodeficiency.

Allogeneic hematopoietic cell transplantation (HCT) remains the only curative treatment for WAS. Matched sibling donor (MSD) transplantation has resulted in event-free-survival $>90 \%$, compared to $70-90 \%$ in matched unrelated donor (MUD) and umbilical cord blood (UCB) and 
$55-90 \%$ in mismatched unrelated donor transplantation (MMUD) (2, 8-11). With the increasing application of haploidentical bone marrow transplantation (haplo-BMT) with post-transplant cyclophosphamide (PT-CY) for hematologic malignancies, there have been a limited number of case reports and small case series in the last 3 years on its use in patients with WAS. Herein, we report two brothers with WAS who underwent successful T-cell replete haplo-BMT from their father using myeloablative conditioning (MAC) and PT-CY. The regimen was well-tolerated, resulting in complete donor engraftment and no acute or chronic graft vs. host disease (GvHD).

\section{CASE SERIES}

The older brother (patient \#2) presented for his 1-year well child visit with eczema and purpura, and was found to have a platelet count of $5 \times 10^{9} / \mathrm{L}$. He was admitted for presumed immune thrombocytopenic purpura (ITP) and received intravenous immunoglobulin (IVIG) with a marginal response in his platelet count. Given the persistent eczema and thrombocytopenia with a low mean platelet volume, genetic testing was performed, which confirmed missense mutation, $291 \mathrm{G}>\mathrm{A}$, in the WAS gene $(\mathrm{R} 86 \mathrm{H})$. He was referred to our hematopoietic cell therapy and transplant program when he was 17 months of age for bone marrow (BM) transplant evaluation. No HLA-matched related or unrelated donor was identified. As his mother was pregnant, the parents indicated that they wished to wait in the event that the upcoming sibling may be a match. In the interim, the patient received monthly infusions of IVIG and IV pentamidine for Pneumocystis jirovecii prophylaxis while his platelet count ranged between 30 and $40 \times 10^{9} / \mathrm{L}$.

Patient \#1 (younger brother) was born 2 years after his brother. While he proved to be an HLA match, he unfortunately had thrombocytopenia and genetic testing confirmed the same mutation in the WAS gene. In his first 7 months of life, his platelet count ranged between 50 and $80 \times 10^{9} / \mathrm{L}$, but he then developed transfusion refractory thrombocytopenia $\left(1-5 \times 10^{9} / \mathrm{L}\right)$, which did not respond to IVIG, steroids, or eltrombopag (12). He had no evidence of splenic sequestration and HLA antibody testing failed to reveal the presence of either class I or II antibodies. Because of his severe purpura, it was therefore decided to proceed to haplo-BMT with the younger sibling first.
Prior to transplantation, both patients underwent testing for donor specific anti-HLA antibodies that were negative. Conditioning was myeloablative and consisted of rabbit antithymocyte globulin $4.5 \mathrm{mg} / \mathrm{kg}$ IV over days -9 to -7 , busulfan (BU) $1 \mathrm{mg} / \mathrm{kg}$ IV q $6 \mathrm{~h}$ for 12 doses on days -8 to -6 , fludarabine (FLU) $30 \mathrm{mg} / \mathrm{m}^{2}$ IV on days -5 to -2 , and melphalan (MEL) $100 \mathrm{mg} / \mathrm{m}^{2}$ IV on day -2 (Figure 1). Busulfan pharmacokinetics were performed after the first dose with an estimated area under the curve (AUC) average exposure of $4.44 \mathrm{mg} \times \mathrm{h} / \mathrm{L}$ per dose for the younger sibling and 4.11 for the older (Table 1). BM stem cells were freshly harvested from their father in both cases. GVHD prophylaxis included PT-CY $50 \mathrm{mg} / \mathrm{kg}$ IV on days +3 and +4 followed by initiation of mycophenolate mofetil (MMF) and tacrolimus on day +5 . In the absence of GvHD, MMF was discontinued on day +28 without taper and tacrolimus was weaned beginning on day +100 over the next 3 months.

Standard bacterial prophylaxis was used (Lefofloxacin) when ANC dropped below $0.5 \times 10^{9} / \mathrm{L}$. Antifungal prophylaxis

TABLE 1 | Patient and transplant characteristics.

\begin{tabular}{|c|c|c|}
\hline Gender & $\mathrm{M}$ & $\mathrm{M}$ \\
\hline Age at BMT (yr) & 0.7 & 4.0 \\
\hline Conditioning & ATG-BFM & ATG-BFM \\
\hline $\mathrm{B} \cup \mathrm{A} \cup \mathrm{C}(\mathrm{mg} \times \mathrm{hr} / \mathrm{L})$ & 4.44 & 4.11 \\
\hline BMT donor & Father & Father \\
\hline HLA match & $5 / 10$ & $5 / 10$ \\
\hline DSA & no & no \\
\hline Donor blood type & $A+$ & $A+$ \\
\hline Recipient blood type & $\mathrm{O}+$ & $\mathrm{AB}+$ \\
\hline $\mathrm{CD}_{3} 4^{+}$cells $\times 10^{6} / \mathrm{kg}$ & 5.41 & 5.12 \\
\hline CD $45^{+}$cells $\times 10^{8} / \mathrm{kg}$ & 3.65 & 4.17 \\
\hline $\mathrm{CD}^{+}$cells $\times 10^{6} / \mathrm{kg}$ & $n / d$ & 0.6 \\
\hline \multicolumn{3}{|c|}{ GvHD prophylaxis (days post-BMT) } \\
\hline PT-CY & $+3,+4$ & $+3,+4$ \\
\hline MMF & +5 to +28 & +5 to +28 \\
\hline Tacrolimus & +5 to +159 & +5 to +172 \\
\hline G-CSF & + & + \\
\hline
\end{tabular}

BFM, busulfan, fludarabine, melphalan; BU AUC, busulfan area under the curve; $D S A$, donor specific anti-HLA antibodies; $n / d$, not done; PT-CY, post-transplant cyclophosphamide; MMF, mycophenolate mofetil.

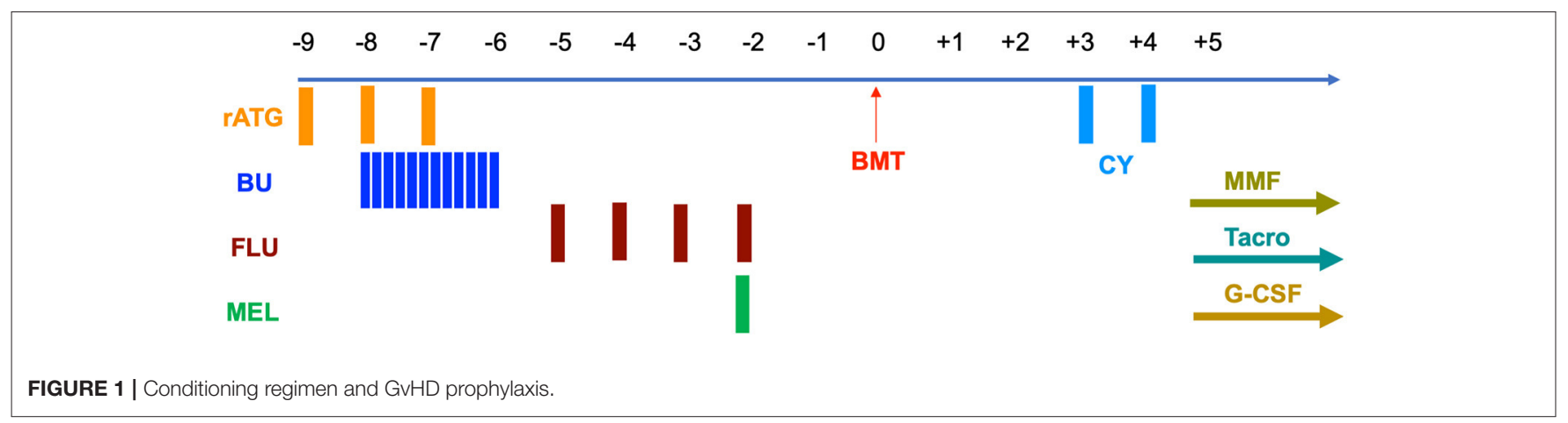


with voriconazole was initiated following completion of $\mathrm{BU}$ administration. For $P$. jirovecii prevention, IV pentamidine was given until 1 year after BMT. Acyclovir was also started on admission for herpes simplex and varicella virus prophylaxis. Bi-weekly polymerase chain reaction (PCR) monitoring for cytomegalovirus (CMV) and weekly for adenovirus, EpsteinBarr virus (EBV), and human herpes virus-6 (HHV-6) were performed until discharge from hospital and subsequently at least every other week during the first 100 days and at least monthly for another 6 months.

Granulocyte-colony stimulating factor (G-CSF) was started on day +5 at $5 \mu \mathrm{g} / \mathrm{kg} /$ day until an absolute neutrophil count (ANC) of $2.5 \times 10^{9} / \mathrm{L}$ was achieved for three consecutive days. Whole blood donor chimerism was evaluated on days $+28,+100,+180$, and +365 . Since both patients had complete donor chimerism, lineage-specific chimerisms were not performed routinely but only at last follow-up, specifically at 27 months for patient \#1 and at 12 months for patient \#2 (Table 2).

Patients and transplant characteristics are summarized in Table 1. Post-transplant courses were very similar with both siblings engrafting promptly with neither one developing signs

\begin{tabular}{|c|c|c|}
\hline Mucositis (grade) & III & $\|$ \\
\hline Days to ANC $>0.5 \times 10^{9} / \mathrm{L}$ & 16 & 13 \\
\hline Days to platelet $>20 \times 10^{9} / \mathrm{L}$ & 36 & 22 \\
\hline Donor Chimerism d +28, +100, +180, +365 (\%) & 100 & 100 \\
\hline T-cell CD3 ${ }^{+}$ & 100 & 100 \\
\hline Myeloid CD33+ & 100 & 100 \\
\hline Donor CMV serology & + & + \\
\hline Recipient CMV serology & + & + \\
\hline $\mathrm{CMV}$ reactivation & No & No \\
\hline Adenovirus reactivation & No & No \\
\hline HHV6 reactivation & No & No \\
\hline EBV reactivation & No & No \\
\hline Gram+ bacteremia & No & No \\
\hline Gram+ bacteremia & Yes & Yes \\
\hline Fungal infection & No & No \\
\hline Acute GvHD & No & No \\
\hline Chronic GvHD & No & No \\
\hline \multicolumn{3}{|l|}{ Immune reconstitution 1 yr $(/ \mu \mid)$} \\
\hline $\mathrm{CD}^{+}$ & 1,759 & 1,200 \\
\hline $\mathrm{CD}^{+}$ & 949 & 666 \\
\hline $\mathrm{CD}^{+}$ & 752 & 399 \\
\hline CD4/CD8 ratio & 1.3 & 1.7 \\
\hline CD19+ & 1,027 & 881 \\
\hline $\mathrm{CD}_{16}{ }^{+} / \mathrm{CD} 6^{+}$ & 127 & 74 \\
\hline IVIG post-BMT (\# doses) & 0 & 1 \\
\hline EFS Post-BMT (mo) & 28 & 12.5 \\
\hline
\end{tabular}

ANC, absolute neutrophil count; EFS, event free survival, lineage specific chimerisms were performed at 27 months and 12 months for patient \#1 and \#2, respectively. of acute or chronic GvHD (Table 2). Except for mucositis, there were no other organ toxicities. No viral reactivations or disease occurred; however, both brothers developed stenotrophomonas maltophilia bacteremia at 4 and 5 months post-BMT, necessitating line removal and antibiotics (Table 2). Only the older brother required a single infusion of IVIG replacement therapy on day +30 post-haplo-BMT. Both siblings are alive and well with normal blood counts at 28 and 12.5 months post-transplant.

\section{DISCUSSION}

While haplo-HCT with PT-CY has been widely used for hematologic malignancies, this approach has only recently emerged for patients with WAS with only a handful of published reports. A study from Brazil described the application of haplo-BMT with PT-CY for primary immunodeficiencies, which included nine patients with WAS (13). Two of the three patients that received the Baltimore reduced intensity conditioning (RIC) (14) failed to engraft while all six of the patients receiving MAC with BU $16 \mathrm{mg} / \mathrm{kg}$ FLU $160 \mathrm{mg} / \mathrm{m}^{2}$ and rabbit ATG had stable engraftment and were alive. The incidence of GvHD was not reported specifically for the WAS patients, but they represented more than a third of a group that had $36 \%$ grade II-IV aGvHD and $17 \% \mathrm{cGvHD}$. Using BU $16 \mathrm{mg} / \mathrm{kg}$ and a slightly lower FLU dose $\left(150 \mathrm{mg} / \mathrm{m}^{2}\right)$ and rabbit ATG, Yue et al. reported five WAS patients from China (15). These patients received a combination of BM and peripheral blood stem cells (PBSCs) from the same donor resulting in no graft failures but with two patients developing cGvHD. Also using BU $16 \mathrm{mg} / \mathrm{kg}$ and FLU $150 \mathrm{mg} / \mathrm{m}^{2}$ but with alemtuzumab instead of ATG was another case series from Israel, which included a patient with WAS receiving haplo-BMT and engrafting without GvHD (16). A case report from Thailand used a lower dose of BU 320 $\mathrm{mg} / \mathrm{m}^{2}$ but much higher dose of FLU $210 \mathrm{mg} / \mathrm{m}^{2}$ and rabbit ATG with engraftment and no GvHD (17). Other case series using different preparative regimens include one from India of primary immune deficiencies undergoing haplo-HCT with PTCY that included five patients with WAS (18). Conditioning appeared to be RIC with FLU-MEL but the doses were not specified. Two of five patients developed graft failure and did not survive, each one having received BM and PBSCs. Of the three patients that engrafted, the two that received PBSCs developed grade II aGvHD and one cGVHD. A patient with WAS from India received PBSCs following myeloablative conditioning with thiotepa (TT) $7 \mathrm{mg} / \mathrm{kg}$, BU $12.8 \mathrm{mg} / \mathrm{kg}$, FLU $150 \mathrm{mg} / \mathrm{m}^{2}$, and rabbit ATG. He achieved engraftment without reported acute or chronic GvHD (19). Finally, in another case from India, rabbit ATG and thiotepa $10 \mathrm{mg} / \mathrm{kg}$ were added to the Baltimore regimen of CY, FLU, and TBI resulting in engraftment following PBSC haplo-transplant without acute or chronic GvHD (20). These reports are summarized in Table 3.

We present two brothers who underwent a T-cell replete haplo-BMT with PT-CY from their father. The siblings received MAC, which we have previously reported in haplo-BMT with 
TABLE 3 | T-cell replete haploidentical HCT reports with PT-CY in patients with Wiskott-Aldrich Syndrome.

\begin{tabular}{|c|c|c|c|c|c|c|c|c|}
\hline & $n$ & Country & $\begin{array}{c}\text { Intensity } \\
n=\end{array}$ & Regimen & $\begin{array}{l}\text { Graft } \\
n=\end{array}$ & $\begin{array}{c}\text { Engraft } \\
n(\%)\end{array}$ & $\begin{array}{c}\text { aGvHD III-IV } \\
n(\%)\end{array}$ & $\begin{array}{c}\text { cGvHD } \\
n(\%)\end{array}$ \\
\hline Fernandes et al. (13) & 9 & Brazil & $\begin{array}{l}\text { RIC } 3 \\
\text { MAC } 6\end{array}$ & $\begin{array}{l}\text { CY-FLU-200cGy } \\
\text { BU-FLU-ATG }\end{array}$ & $\mathrm{BM}$ & $\begin{array}{c}2(67) \\
6(100)\end{array}$ & NR & NR \\
\hline Yue et al. (15) & 5 & China & MAC & BU-FLU-ATG & $\mathrm{BM}+\mathrm{PBSC}$ & 5 (100) & 0 & $2(40)$ \\
\hline Even-Or et al. (16) & 1 & Israel & MAC & BU-FLU-ALEMTUZ & $\mathrm{BM}$ & $1(100)$ & 0 & 0 \\
\hline Kreetapirom et al. (17) & 1 & Thailand & MAC & BU-FLU-ATG & PBSC & $1(100)$ & 0 & 0 \\
\hline Uppuluri et al. (18) & 5 & India & $\begin{array}{l}\text { RIC } 4 \\
\text { MAC } 1\end{array}$ & $\begin{array}{l}\text { FLU-MEL } \\
\text { FLU-TREO-200 cGy }\end{array}$ & $\begin{array}{l}\text { PBSC 3, } \\
\text { BM } 2\end{array}$ & $3(60)$ & 0 & $1(20)$ \\
\hline Sharma et al. (19) & 1 & India & MAC & TT-BU-FLU-ATG & PBSC & $1(100)$ & 0 & 0 \\
\hline Thakkar et al. (20) & 1 & India & $\mathrm{RIC}$ & TT-BU-FLU-ATG & PBSC & $1(100)$ & 0 & 0 \\
\hline Katsanis, current & 2 & Tucson AZ, US & MAC & BU-FLU-MEL & $\mathrm{BM}$ & $2(100)$ & 0 & 0 \\
\hline
\end{tabular}

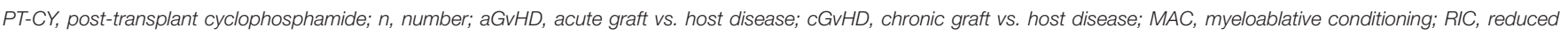

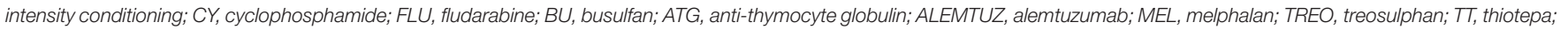
$B M$, bone marrow; PBSC, peripheral blood stem cells; NR, not reported.

PT-CY for hematologic malignancies and consists of BUFLU-MEL but with the addition of rabbit ATG (21-23). Our preparative regimen has only 3 days of $\mathrm{BU}(12 \mathrm{mg} / \mathrm{kg})$ and a lower dose of FLU $\left(120 \mathrm{mg} / \mathrm{m}^{2}\right)$ than the aforementioned regimens, as MEL is added to the last day of FLU. As indicated above, this regimen was well-tolerated with minimal organ toxicity limited to mucositis, trilineage engraftment with complete donor chimerism, no acute or chronic GvHD, no bacterial infections in the first 3 months post-BMT, and no fungal infections or viral reactivations. $\mathrm{BU}$-based $\mathrm{MAC}$ conditioning regimens are more commonly used in WAS with MSD, MUD, MMUD, and UCB transplants and found to be associated with decreased graft failure and lower incidence of mixed chimerism when compared to RIC $(2,8-10)$. This also appears to be true with haplo-HCT as RIC regimens had higher numbers of patients with WAS developing graft failure $(13,18)$. While the numbers of patients with WAS reported to have received haplo-HCT is small, there appears to be a trend of more aGvHD and cGvHD in those receiving $\mathrm{PBSC}$ compared to $\mathrm{BM}$ as has been documented in other transplant settings (24-26).

As WAS is an X-linked disorder, with an incidence of 1-4 per 1 million males, it would not be uncommon to have more than one boy in a family with this diagnosis. Our experience is unique as there have not been other reports of two brothers with WAS receiving haplo-BMT from the same donor, in this case their father. Moreover, it illustrates that haplo-BMT from the same donor, preferably the father, can be readily performed and be curative. While mothers, who are WAS carriers, have been used in some cases, haploidentical fathers or brothers are preferable. Additionally, the risk of GvHD is believed to be lower when male donors are used for male recipients compared to female donors. It is believed that female donor T cells may react to minor histocompatibility antigens encoded by genes present in the $\mathrm{Y}$ chromosome (27).

Our patients were of mixed race, their two sisters were not an HLA match, and unrelated searches failed to identify suitable matches as is the case more often than not for minority populations (28). Considering the difficulty in finding matched unrelated donors for minority patients, haplo-BMT with PTCY has quickly become an acceptable alternative not only for hematologic malignancies but also non-malignant disorders such as WAS. Moreover, haploidentical familial donors, especially parents, are often eager to donate, dependable, and readily available for not only the initial BM donation but also additional collections as was the case with the father in our report. In summary, our cases, in addition to other recently published reports, indicate that MAC followed by haplo-HCT with PTCY may be a safe and effective alternative to MUD and UCB transplantation for patients with WAS; however, it remains to be confirmed in a larger cohort of patients.

\section{DATA AVAILABILITY STATEMENT}

The raw data supporting the conclusions of this article will be made available by the authors, without undue reservation.

\section{ETHICS STATEMENT}

The studies involving human participants were reviewed and approved by Human Subjects Protection Program The University of Arizona. Written informed consent to participate in this study was provided by the participants' legal guardian/next of kin.

\section{AUTHOR CONTRIBUTIONS}

EK wrote the manuscript and managed the patients during their hematopoietic cell transplantation. JS and JA reviewed the clinical records and co-wrote the manuscript. NR and PA edited the manuscript and treated the patients before transplantation.

\section{ACKNOWLEDGMENTS}

The authors would also like to thank the inpatient and outpatient nursing and other staff on the pediatric HCTT unit at Banner University Medical Center in Tucson, AZ for their outstanding care of our patients. 


\section{REFERENCES}

1. Notarangelo LD, Miao $\mathrm{CH}$, Ochs $\mathrm{HD}$. Wiskott-Aldrich syndrome. Curr Opin Hematol. (2008) 15:30-6. doi: 10.1097/MOH.0b013e3282 f30448

2. Ochs HD, Filipovich AH, Veys P, Cowan MJ, Kapoor N. WiskottAldrich syndrome: diagnosis, clinical and laboratory manifestations, and treatment. Biol Blood Marrow Transplant. (2009) 15 (1 Suppl.):84-90. doi: 10.1016/j.bbmt.2008.10.007

3. Mahlaoui N, Pellier I, Mignot C, Jais JP, Bilhou-Nabera C, Moshous D, et al. Characteristics and outcome of early-onset, severe forms of Wiskott-Aldrich syndrome. Blood. (2013) 121:1510-6. doi: 10.1182/blood-2012-08-448118

4. Notarangelo LD, Mazza C, Giliani S, D’Aria C, Gandellini F, Ravelli C, et al. Missense mutations of the WASP gene cause intermittent X-linked thrombocytopenia. Blood. (2002) 99:2268-9. doi: 10.1182/blood.V99.6.2268

5. Notarangelo LD, Ochs HD. Wiskott-Aldrich syndrome: a model for defective actin reorganization, cell trafficking and synapse formation. Curr Opin Immunol. (2003) 15:585-91. doi: 10.1016/S0952-7915(03)00112-2

6. Jin Y, Mazza C, Christie JR, Giliani S, Fiorini M, Mella P, et al. Mutations of the Wiskott-Aldrich syndrome protein (WASP): hotspots, effect on transcription, and translation and phenotype/genotype correlation. Blood. (2004) 104:40109. doi: 10.1182/blood-2003-05-1592

7. Ochs HD, Notarangelo LD. Structure and function of the WiskottAldrich syndrome protein. Curr Opin Hematol. (2005) 12:284-91. doi: 10.1097/01.moh.0000168520.98990.19

8. Burroughs LM, Petrovic A, Brazauskas R, Liu X, Griffith LM, Ochs HD, et al. Excellent outcomes following hematopoietic cell transplantation for Wiskott-Aldrich syndrome: a PIDTC report. Blood. (2020) 135:2094-105. doi: 10.1182/blood.2019002939

9. Ozsahin H, Cavazzana-Calvo M, Notarangelo LD, Schulz A, Thrasher AJ, Mazzolari E, et al. Long-term outcome following hematopoietic stem-cell transplantation in Wiskott-Aldrich syndrome: collaborative study of the European Society for Immunodeficiencies and European Group for Blood and Marrow Transplantation. Blood. (2008) 111:439-45. doi: 10.1182/blood-2007-03-076679

10. Shekhovtsova Z, Bonfim C, Ruggeri A, Nichele S, Page K, AlSeraihy A, et al. A risk factor analysis of outcomes after unrelated cord blood transplantation for children with Wiskott-Aldrich syndrome. Haematologica. (2017) 102:1112-9. doi: 10.3324/haematol.2016.158808

11. Moratto D, Giliani S, Bonfim C, Mazzolari E, Fischer A, Ochs HD, et al. Longterm outcome and lineage-specific chimerism in 194 patients with WiskottAldrich syndrome treated by hematopoietic cell transplantation in the period 1980-2009: an international collaborative study. Blood. (2011) 118:1675-84. doi: 10.1182/blood-2010-11-319376

12. Gerrits AJ, Leven EA, Frelinger AL, 3rd, Brigstocke SL, Berny-Lang MA, Mitchell WB, et al. Effects of eltrombopag on platelet count and platelet activation in Wiskott-Aldrich syndrome/X-linked thrombocytopenia. Blood. (2015) 126:1367-78. doi: 10.1182/blood-2014-09-602573

13. Fernandes JF, Nichele S, Arcuri LJ, Ribeiro L, Zamperlini-Netto G, Loth $\mathrm{G}$, et al. Outcomes after haploidentical stem cell transplantation with post-transplantation cyclophosphamide in patients with primary immunodeficiency diseases. Biol Blood Marrow Transplant. (2020) 26:1923-9. doi: 10.1016/j.bbmt.2020.07.003

14. Klein OR, Buddenbaum J, Tucker N, Chen AR, Gamper CJ, Loeb D, et al. Nonmyeloablative haploidentical bone marrow transplantation with post-transplantation cyclophosphamide for pediatric and young adult patients with high-risk hematologic malignancies. Biol Blood Marrow Transplant. (2017) 23:325-32. doi: 10.1016/j.bbmt.2016.11.016

15. Yue Y, Shi X, Song Z, Qin J, Li J, Feng S, et al. Posttransplant cyclophosphamide for haploidentical stem cell transplantation in children with Wiskott-Aldrich syndrome. Pediatr Blood Cancer. (2018) 65:e27092. doi: $10.1002 /$ pbc. 27092

16. Even-Or E, NaserEddin A, Dinur Schejter Y, Shadur B, Zaidman I, Stepensky P. Haploidentical stem cell transplantation with post-transplant cyclophosphamide for osteopetrosis and other nonmalignant diseases. Bone Marrow Transplant. (2020) 56:434-441. doi: 10.1038/s41409-020-01040-9

17. Kreetapirom P, Hongeng S, Manuyakorn W, Anurathapan U, Pakakasama $\mathrm{S}$, Sirachainan $\mathrm{N}$, et al. Successful HLA haploidentical HSCT with post-transplant cyclophosphamide in Wiskott-Aldrich syndrome. Bone Marrow Transplant. (2017) 52:913-4. doi: 10.1038/bmt.2017.25

18. Uppuluri R, Sivasankaran M, Patel S, Swaminathan VV, Ramanan KM, Ravichandran N, et al. Haploidentical stem cell transplantation with posttransplant cyclophosphamide for primary immune deficiency disorders in children: challenges and outcome from a tertiary care center in South India. J Clin Immunol. (2019) 39:182-7. doi: 10.1007/s10875-019-00600-Z

19. Sharma A, Rastogi N, Kapoor R, Chatterjee G, Yadav SP. Successful haploidentical stem cell transplant with posttransplant cyclophosphamide in Wiskott-Aldrich syndrome with myeloablative conditioning. J Pediatr Hematol Oncol. (2021) 43:e230-3. doi: 10.1097/MPH.0000000000001841

20. Thakkar D, Katewa S, Rastogi N, Kohli S, Nivargi S, Yadav SP. Successful reduced intensity conditioning alternate donor stem cell transplant for Wiskott-Aldrich syndrome. J Pediatr Hematol Oncol. (2017) 39:e493-6. doi: 10.1097/MPH.0000000000000959

21. Katsanis E, Sapp LN, Reid SC, Reddivalla N, Stea B. T-cell replete myeloablative haploidentical bone marrow transplantation is an effective option for pediatric and young adult patients with high-risk hematologic malignancies. Front Pediatr. (2020) 8:282. doi: 10.3389/fped.2020.00282

22. Katsanis E, Maher K, Roe D, Simpson RJ. Progressive substitution of post-transplant cyclophosphamide with bendamustine: A phase I study in haploidentical bone marrow transplantation. eJHaem. (2020) 1:1-7. doi: $10.1002 /$ jha2.20

23. Katsanis E, Sapp LN, Varner N, Koza S, Stea B, Zeng Y. Haploidentical bone marrow transplantation with post-transplant cyclophosphamide/bendamustine in pediatric and young adult patients with hematologic malignancies. Biol Blood Marrow Transplant. (2018) 24:2034-9. doi: 10.1016/j.bbmt.2018.06.007

24. Anasetti C, Logan BR, Lee SJ, Waller EK, Weisdorf DJ, Wingard JR, et al. Peripheral-blood stem cells versus bone marrow from unrelated donors. $N$ Engl J Med. (2012) 367:1487-96. doi: 10.1056/NEJMoa1203517

25. Mehta RS, Peffault de Latour R, DeFor TE, Robin M, Lazaryan A, Xhaard A, et al. Improved graft-versus-host disease-free, relapse-free survival associated with bone marrow as the stem cell source in adults. Haematologica. (2016) 101:764-72. doi: 10.3324/haematol.2015.138990

26. Nagler A, Dholaria B, Labopin M, Savani BN, Angelucci E, Koc Y, et al. Bone marrow versus mobilized peripheral blood stem cell graft in T-cell-replete haploidentical transplantation in acute lymphoblastic leukemia. Leukemia. (2020) 34:2766-2775. doi: 10.1038/s41375-0200850-9

27. Ciurea SO, Al Malki MM, Kongtim P, Fuchs EJ, Luznik L, Huang XJ, et al. The European Society for Blood and Marrow Transplantation (EBMT) consensus recommendations for donor selection in haploidentical hematopoietic cell transplantation. Bone Marrow Transplant. (2020) 55:12-24. doi: 10.1038/s41409-0190499-z

28. Gragert L, Eapen M, Williams E, Freeman J, Spellman S, Baitty R, et al. HLA match likelihoods for hematopoietic stem-cell grafts in the U.S. registry. NEngl J Med. (2014) 371:339-48. doi: 10.1056/NEJMsa1311707

Conflict of Interest: The authors declare that the research was conducted in the absence of any commercial or financial relationships that could be construed as a potential conflict of interest.

Publisher's Note: All claims expressed in this article are solely those of the authors and do not necessarily represent those of their affiliated organizations, or those of the publisher, the editors and the reviewers. Any product that may be evaluated in this article, or claim that may be made by its manufacturer, is not guaranteed or endorsed by the publisher.

Copyright (c) 2021 Smith, Alfonso, Reddivalla, Angulo and Katsanis. This is an open-access article distributed under the terms of the Creative Commons Attribution License (CC BY). The use, distribution or reproduction in other forums is permitted, provided the original author(s) and the copyright owner(s) are credited and that the original publication in this journal is cited, in accordance with accepted academic practice. No use, distribution or reproduction is permitted which does not comply with these terms. 